\title{
1 \\ Blasphemy and sacrilege: A challenge to secularisation and theories of the modern?
}

\section{David Nash}

In the penultimate episode of the recent beloved BBC science fiction series $\mathrm{Dr}$ Who the massed ranks of the Daleks made a long awaited re-appearance. In doing so they demonstrated a developed conception of amoral violence and the justification for it in a conception of blasphemy. When confronted by the possibility that they might contain human DNA, the Daleks considered this to be a suggestion that was potentially blasphemous. This is arguably a quite significant cultural moment for the confidence that underpinned our modernist vision of civilisation. The Daleks after all were created in the early 1960s, arguably the highpoint of post-war confidence in humanity's capacity to sort out social and economic problems. At this time, the Dalek was literally a modernist dustbin into which all that was unsavoury in human interaction was consigned. Yet the Daleks have returned to a world that has (since they've been gone) seen the concepts of 'ethnic cleansing', 'collateral damage', 'hate crime' and 'The War on Terror' emerge. The violent and unsavoury material consigned to the bin is climbing out to recolonise a world once thought confidently civilised. Moreover, it is concepts like blasphemy and other species of violent attack upon identity that potentially provides for the emergence of a more confrontational and violent world.

Discourses of blasphemy that might lead to its detection and indeed committal are back with a vengeance and offer to trail blaze a path for religion and religious responses. They are also seeking to become the highway leading towards the new politics of cultural identity. Moreover, discourses of blasphemy are invading culture itself to become something of a catch-all term that allows individuals to display frustration and to place distance and difference between themselves and others. Most of us in the West have considered religious and cultural tolerance to be an intrinsic and cherished part of the modernist dream. The modern world's communications technology seems to present an inescapable power that should transcend hatred, anger and misunderstanding. These days we can share our innermost thoughts and feelings with other people without facing or interacting with them. The internet has made this possible, fostering the growth of our own 
personal world of interests and adding apparent authority and validity to ever divergent opinions. Today we have an information society that is potentially overloaded with both facts and opinion. But, strangely, this 'opinion rich' society has become a society that has never seen individuals and groups more in conflict.

\section{Freedom of expression and its development}

The reaction to alien views in contemporary worlds and the historic past has quite often been termed blasphemy. In some respects it is easy to say that the outpourings of others deserve consideration and recognition whether or not their discourses or statements are coherent. But history reminds us that we must confront the consequences of the freedom that the modern world has given us. While those who fought for the extension of forms of democracy in the post-war world would celebrate the downfall of spurious and enslaving authority, the gap that this loss of authority left was large and threatening. Indeed, we should remember that there are important reasons for describing this situation as a gap. This became plain in a significant range of cultural discourses that talked about the 'end' of such reassuring concepts as civilisation, history, and, of course, the modernist project. Such discourses looked back at supposed species of tyranny and constraint that had apparently been transcended but scarcely, if at all, looked forward to a world of potential liberation and open ended expression. For the optimistic, and those who never gave a second thought to the fact that they themselves were empowered by culture, the future represented a wealth of opportunities. Clearly, empowerment was precisely the key to this so-called liberation. Those who had benefited from the material consequences of the modernist project, for example, through education, or through access to the public sphere and the media had simultaneously the wish, the means, and the ability to express themselves and to influence others. Paradoxically, the breakdown of confidence in these same mechanisms left others without such forms of liberation or expression. Moreover, this also contributed to their long-term loss of confidence in their own empowerment through the opportunities offered by the West.

The breakdown of this confidence emphasises how far we have grown deeply accustomed to writing an especially Whig, socio-democratic progressivist style history of both religion and rights in the West. A pejorative attitude to religion was also often present in modernisation theory which considered superstition and forms of belief to belong to primitive epochs and that these represented a phase through which human development passed. ${ }^{1}$ Traditionally, Whig religious history has told us that religious tolerance has developed in Western nation states as a consequence of these states conceding species of human rights. This concession of human rights often went hand in hand with these states surrendering stewardship and authority over the ideological makeup of their citizen's moral and mental lives. Generally speaking, this stewardship was 
considered to be of a religio-moral nature and its withering away within this historical model of progress was often linked to the sociological theory of secularisation. In one branch of this theory, offered substantially in the 1960s by the then influential work of Peter Berger, the supposed authority of religion in the areas of behavioural morality, education and welfare were deemed to have been broken by developments within the post-war world. ${ }^{2}$ Such developments had arguably been at work since the Enlightenment. Teleological notions of society's development from Hegel, Marx, Weber, Elias and Foucault envisaged the marginalisation of religion into various components. Whether this was brought about by revolution (Hegel/Marx), greater specialisation (Weber), civility (Elias), or the growth of the subjectively empowered self (Foucault), all theories predicted its potential demise.

A brief reflection over the last paragraph will alert readers to how old fashioned the secularisation paradigm sketched actually looks — yet systematic discrediting of its assumptions and conclusions is still required. Interestingly, the modernisation and peaceful transition model of religious change has a stunning longevity and some commentators have noted the capacity for such accounts to overwrite conflict models. ${ }^{3}$ In his examination of the archaeological evidence of religious violence from the classical world, Eberhard Saur examined how the archaeological processes of excavation and restoration are capable of denying the phenomenon of iconoclasm. In discussing the public display and portrayal of one statue (the statue of Mithras from Ostia), Saur notes that its archaeological value is too often considered through its carefully restored state. In this, the mutilation of the statue has been forgotten and similar evidence of destruction, so Saur argues, has been neglected or ignored. A factor that obscures the history of religious conflict still further is what Saur describes as a trend within archaeological explanations of change to adopt gradualist models of 'acculturation'. Acculturation models argue for a much more gradual interleaving of cultures based around peaceful contact, mutual sharing of technology and cultural achievements - all opposed to ideas of conquest and cultural imperialism. Interestingly, this bears a striking resemblance to modern perceptions of the functioning and purpose of religious/multicultural tolerance. Of still greater concern is Saur's suggestion that the advocates of 'acculturation' theses of change are apt to describe destructive conflict models of change as old fashioned and shaped by discredited nineteenth century paradigms. ${ }^{4}$

Similarly, the Reformation was regularly described as a linear unstoppable process which came fundamentally to alter the social and religious makeup of the West. In this we are persuaded that the building blocks of modernism (constructed by More and Erasmus) were firmly in place before Marx, Hegel, Weber, and even Nietzsche put pen to paper. Likewise, the triumph of the Newtonian rational universe noted in the history of science and even within the histories of gambling and probability portrays a modernisation motif which 
explains rationality as the triumphant explanatory framework around which the universe turns. ${ }^{5}$ No longer did the turn of the dice or the shape of natural phenomena or laws display the divine will but instead could be explained through natural laws or the secular notion of probability.

Saur reminds us how archeological models that display destruction and iconcoclasm are worth taking with us in any study of secularisation as a consensual linear and modernising history. Attacks upon religious images represent a significant portion of blasphemy's early history. Blasphemy in the ancient and early Christian periods most frequently comes down to the historian as the written record of individual acts of outrage. Like many other crimes, there must also have been a dark figure of iconoclastic acts against religious material culture that have subsequently left no trace. The wilful and calculated destruction of religious artefacts or buildings displayed an intent to damage the religious 'currency' of the religion so attacked. Evidence from the ancient world strongly suggests that monotheistic religions took the lead in iconoclastic practices and the identification of other religions as anathema. Pre-Christian Rome had been indulgent to both empire-wide and local deities and archaeologists have seen the widespread existence of some cults as tangible evidence of this. Individual deities were chosen for their usefulness and augmented existing belief systems rather than displaced them. It was monotheistic religions that set themselves against this equilibrium. ${ }^{6}$

The creation of a single autonomous religious truth and route to salvation provides the obvious explanation as to why this was clearly the case. When Pharaoh Akhenaten adopted monotheism in ancient Egypt the destruction of rival deities was a logical and inevitable consequence of this choice. Judaism similarly had scriptural precedent for violent action against pagan deities, although some of these examples were aimed at religious usurpation or the Israelites 'straying' from the true God. After Christianity's arrival, the trend was continued further by Islam's adoption of iconoclastic practices. As Islam spread East its iconoclasm left its mark upon the Buddhist shrines and idols of India.

Later Christianity also regarded pagan relics and practices to be capable of routinely contaminating the lives of true believers. The systematic nature of Christian iconoclasm can be contrasted with the haphazard and inconclusive actions of Roman predecessors. Sauer suggests that the Emperor Aurelian's capture of Palmyra resulted in half-hearted and piecemeal destruction of local sacred places and, perhaps, even represented a tolerance or respect for the deities of the defeated city. ${ }^{7}$

In sum, the linear models of secularisation producing and being sustained by tolerance and rationality from the Enlightenment to the dawn of modernisation deserve to be qualified if not wholly questioned. Models of acculturation, of which secularisation is surely one, can be shown to have overshadowed models 
of conflict and episodic reaction. Similarly the post-Enlightenment 'invention' of religious tolerance ignores the relative tolerance that existed within some early civilisations.

\section{Blasphemy and the framing of secularisation}

One relic of modernisation and Whig history that still has lingered longer than most is the theory of secularisation, although the secularisation theory which strove to have a dominant place in the history and sociology of religion has now retreated somewhat in the face of a number of intellectual and theoretical challenges, particularly from historians. If the theory of secularisiation no longer claims to offer an overarching explanation of the last millennium of Christianity's history, it can at least point to its description of general trends in belief and outlook as maintaining its validity. Secularisation theory, in various forms, suggests that the modern world is more secular than the pre-modern, and this in turn more secular than the medieval. It points to a whole host of indicators that have altered mankind's perception of the world and how it functions. These include the arrival of scientific beliefs to replace belief in providence, the transfer of education, welfare and medicine into the secular sphere and, lastly, the end of mass religious attendance accompanied by the retreat of religion from public life. ${ }^{8}$ Moreover, secularisation's theoretical account of the historical past suggests that episodes such as the Reformation, the rise of Protestantism and the Enlightenment constitute milestones towards the creation of this secular society. The high watermark of confidence in the theory of secularisation occurred a generation ago, but it remains arguable that modern society is overall more secular than previous epochs.

However, blasphemy's history significantly contests the certainty and inevitability of this view of historical progress and offers a significantly different chronology for religious history. Certainly, it may be possible to argue that blasphemy itself represents a 'secularisation' of the concept of heresy. Heretics were quite regularly cast as victims of their errors that entered their minds unwittingly. Most medieval and early modern accounts of blasphemers see them as wilful individuals indulging their own pride. The investigations of early modern Germany, France and Switzerland would lend credibility to this view. ${ }^{9}$ The offence of blasphemy became one of active commission whereby doubts or errant opinions were actively vocalised within the earshot of others. In contrast to heresy, blasphemy was increasingly considered to be a lapse of discipline rather than sincere religious error. Many medieval European cases display individuals as drunk or angry at some slight providence had wrought upon them. Others attacked the honour of God in anger against the ill fortune he had bestowed upon them, frequently at the gambling table. ${ }^{10}$

Nonetheless, other assumptions of the secularisation account of religion's supposedly waning importance do not fit with blasphemy's very different 
history. The Reformation, far from diluting the sacred, shifted the focus to scripture and the Bible. New light is also shed on this through noting how mediaeval conceptions of sin and shame equally had their later Protestant counterparts. ${ }^{11}$ The Enlightenment, it might be argued, brought philosophical and later artistic questioning of the sacred and its place in society. This would fit with the history of the offence in England where French Revolution ideals were later replaced by arguments about free speech, individualism, and the removal of religion to the private sphere. Nonetheless, such a triumph was not linear, nor was it remotely complete since the link between church and state in England was never overthrown.

Secularisation theory itself has also never been comfortable in measuring Christianity's vibrancy within the realm of the private sphere. While it prefers to see privatisation as the story's conclusion, recent history has shown the sacred as capable of being mobilised from this area with a rapidity that would astonish the previous generation. In Britain at the end of the twentieth century and into the new millennium, isolationist agendas have sought to protect both Britain and its component nations from the European super state arguing for 'opt outs' in issues around obscenity and morality. In 1996, for example, a case reached the European Court in which the film maker Nigel Wingrove appealed against the refusal of the British Board of Film Classification to award an exhibition certificate on the grounds it breached his freedom of expression. The court eventually found in favour of the British government allowing it the margin of appreciation, a means by which important cultural areas that might be covered by overarching European Union Law would be allowed to opt out from this. Britain thus was allowed to keep a working legal concept of blasphemy alive. More damning evidence still comes from America, where an institutionalised cleavage between Church and State did not remove the concept of blasphemy from this society. Nor did the Constitution actively secularise American society, forcing religion into the private sphere. Religion has become a central part of American politics and has developed a rhetoric which increasingly attempts to define the state as secular rather than neutral, and is therefore able to describe secular stances and world views as unconstitutional if practiced by the government. $^{12}$ Even where it might be claimed that religion was successfully privatised, the conclusions we might draw from the evidence do not support components of the secularisation thesis. Religion becoming a matter for the private conscience occurred at precisely the same time as knowledge of the law and access to it became a real possibility for more individuals in the West.

Secularisation theorists argued that tolerance would be bred by greater contact between individuals, and that globalisation would homogenise religious outlooks and lessen differences between faiths and groups. In some respects the ecumenical agendas of Western churches in the 1960s and 1970s represents a good example of this, as does the modernisation agenda of Vatican II. Similarly, the arrival of 
scientific beliefs to replace beliefs in providence, and the aforementioned secularisation of education, welfare and medicine, accompanied the retreat of religion from public life. ${ }^{13}$ This confidence has not been borne out by the evidence of the late twentieth century that has seen individuals reach for blasphemy as a tool capable of preventing the erosion of the sacred. For some individuals and groups, defending religion has rejuvenated nationalism in the face of the twin agendas of globalisation and, in particular, pan-European systems of morals and justice.

In England, blasphemy cases as far apart as the 1880s, the 1930s, the 1970s and the 1990s, all contained a fear of continental influences contaminating 'sacred' English morals. The case against Nigel Wingrove's film Visions of Ecstasy allowed the United Kingdom to maintain the Common Law of blasphemous libel as an element of its culturally distinct identity, similarly Mary Whitehouse had invoked the sacred nature of British morality in her campaign to exclude Jens Jurgen Thorsen's Sex Life of Christ from being shot in England in 1977. In accepting these as legal and policy decisions, English fears of the dangerous and foreign were enshrined in and influenced legal decisions. ${ }^{14}$ Elements of these fears were evident in the cases against G.W. Foote in 1883, where the relevant newspaper's blasphemy could be shown to be directly influenced by French prototypes. In the 1930s Britain also witnessed an attempt to extend the blasphemy law as a means of excluding 'foreign' Jewish freethinkers and their ability to undermine the morals of the British Empire. Although this Bill passed a first reading in Parliament, the government moved swiftly to prevent it becoming law. The early 1990s saw the Salman Rushdie affair persuade some to see blasphemy as a multicultural issue. One of the arguments used was the suggestion that Britain's tolerance of other religions and cultures was a sham unless the law could be mobilised to protect the religious sensibilities of all. Early twentieth century America also witnessed a number of panics associated with the dangerous spirituality and anti-religious views of recent immigrants. In the immediate First World War period, a Lithuanian, Michael Mockus, stood trial for blasphemy and, upon conviction, the judge made clear reference to the potentially dangerous views held by immigrants. Mockus linked Christianity with class and economic oppression and argued that religion was essentially a conspiracy against the workers of the world. ${ }^{15}$ Seventeenth century America had seen individual states operate their own penal codes, but latter day America also witnessed the use of blasphemy as a tool for the defence of local communities and their morals. The early twentieth century in particular saw American States pursuing blasphemers within their local and state jurisdictions (recognisably similar to early modern Geneva, Zurich or Venice) only to see these attempts to prosecute and convict quashed by federal law. ${ }^{16}$ Nonetheless, individual communities have for some years now been able to operate their own local standards of decency in defiance of Federal law's long standing desire for equality 
of practice. ${ }^{17}$ Thus, secularisation theory clearly does not offer any valuable framework to explain blasphemy's history and in particular its persistence. Moreover, it is possible to go further and argue that blasphemy's own history itself provided important material for a wider history of the sacred. Its persistence and its current relevance supply vital evidence of the survival of the sacred not simply as a spiritual legacy but as a vital component of beliefs about nationalism and wider religious identity.

Many of our models (especially theoretical ones) concerning long term continuity and change offer inadequate explanations of blasphemy. The phenomenon itself does not readily fit with theories associated with modernisation and change. Following such models and their cultural intentions leads us to ask why blasphemy was not eradicated through the Enlightenment's search for freedom of belief and expression. If theories about the inevitable demise of religion were true, it could be expected that the crime of blasphemy would have been swept away by the eighteenth and nineteenth century revolutions in America and Europe, or fallen into desuetude in the more organic constitutions of Britain and its former English-speaking empire. In the non-English speaking world, the imposition of supposedly enlightened laws from the mother country ironed out local differences to provide what some have seen as an enduring solution. ${ }^{18}$ The survival of blasphemy as a crime, and as an accusation, also offers a temptation to suggest that blasphemy as a cultural phenomenon may suit a more dystopian view of the West in crisis. Those Western critics who were (and are) suspicious of the Enlightenment, and its supposed empowerment of the individual, are the important figures here. Foucault, Derrida and the postmodernists not only regard this empowerment to be a sham but also are likely see the supposed authority of Enlightenment truth as a collection of controls whose ultimate explanatory cohesion disintegrates before them.

\section{Blasphemy, identity and exploration}

Blasphemy was, and is, more than a transgressionary activity. Its long history suggests that controversies about blasphemy are places where definitions of the universe and its working are debated; places where identities are forged and where communities debate issues about public order. All these lead us to a history away from the certainties offered by secularisation narratives. Blasphemy always reminded us that the relationship between individuals and the sacred were very often problematic. Secularisation theorists always spoke about ideas of collective, normal, and everyday belief, thereby homogenising both the experience of belief and the definitions that historians and sociologists would give to it. Blasphemy's illumination of conflict models and incidents showed that belief was capable of ebbing and flowing and appearing at pressure points in the interactions of individuals and societies. In this, the inevitable triumph of the secular over the sacred looks a far-fetched suggestion. Even if secularisation 
theorists did have some justification in arguing that religion would become less important, it remains a teleological theory of progress and continual enlightenment. But the religion supposedly supplanted by reason was not by any means destroyed or damaged beyond repair, and secularisation theorists failed to pay much attention to the residues and legacies that Christianity left in the West.

Artists who explore and contemplate the West's myths, stories and cultural legacy became the people who rescued religion from its appointed status on the periphery of experience. What motivates artistic consideration of the sacred, and why artists as diverse as Andres Serrano, Bettina Rheims, Tracey Emin and Tania Kovats have quarried the sacred for inspiration, are important questions. While these artists themselves may have lucid, exciting and informative answers, the wider 'influence' of the sacred needs to form exploration of the fuller context in this area. ${ }^{19}$ In this respect, it is valuable to ask how far this art reflects a re-discovery or re-orientation around the sacred imagery of the past, or a simple acknowledgement of religion's enthralling nature as one of the West's strongest and most compelling 'stories'. In this, it has not been for many of these artists a re-evangelisation of life, or necessarily a quest for spiritual longing, but has equally sometimes been spawned by the simple curiosity of those brought up with secular outlooks.

This interest means that investigations of popular culture and media studies will inevitably be drawn to the sporadic appearance of the sacred in popular culture. In a sense, each particular media can be said to have its fifteen minutes in the spotlight. Irving Welsh showed the power of disreputable images of the almighty to shock in the context of the modern novel. His Granton Star Cause depicted a profane and drunken deity and was the last controversy Mary Whitehouse, Britain's premier twentieth-century critic of media morality, was involved in before her death. Madonna's sense of melodrama almost inevitably took her in the direction of the sacred long before she thought of actually being crucified on stage. In 2006, her 'Confessions' tour played with Catholic motifs and extended her belief that suffering and crucifixes could be 'made sexy'. Even culturally conservative British comedy, which always wishes it was more subversive than it ever manages to be, produced a publication with religious offensiveness as a keynote feature. The British comedian Rik Mayal's recent autobiography contained a picture of himself beatified and described as 'better than God'. All these are in danger of demonstrating a de facto cheapening and ubiquitousness of the sacred while noting the rediscovery of religion's powers to shock. Yet equating these with outright blasphemy brings problems of intention when, for example, Maddona had embarked on a quest to entertain as much as to problematise or inform her audience about religion and the sacred. 
In particular, we might note how images and portrayals of Christ on film have caused especial problems of interpretation sometimes leading to accusations of blasphemy. Of greater concern have been the attempts to humanise Christ which, in some eyes, appeared to be an assault upon the idea of his divinity a constant struggle in such depictions. Dennis Potter's Son of Man portrayed a Christ at war with himself and sceptical of the divine nature of his own destiny. Similarly, Scorsese's Last Temptation gave critics, both hostile and sympathetic, an opportunity to air the sheer variety of interpretation to which the gospel story, and its depiction, could be subjected. Yet, conclusions from this area were not readily transferable to other blasphemous instances. Films, and their subsequent greater availability on video, are capable of multiple consumption and re-consumption in the quest for favourable or unfavourable meanings. ${ }^{20}$ But the engagement of artists and writers with the religious has provided the opportunity for religious world views to challenge ownership of these cultural ideas and have asked the searching question of whether the ideas of the religious belong to society as a whole. The protests against everything from Last Temptation of Christ to Jerry Springer the Opera have given religious individuals the opportunity to bring arguments about the sacred and its inviolability back to the public sphere. In this they are aided by agendas which promote social inclusiveness and the urge to marginalise differences of opinion and viewpoints in the more consensually driven societies of the new millennium.

These are all conundrums and challenges to artists and thinkers. In such a climate, it is scarcely surprising that a cultural phenomenon so capable of controversy should excite and fascinate the artistic mind used to sifting and redefining the problem areas of civilisation. In the end, we should protect such rights and imperatives since they offer a blueprint for possible change against regimes of abject quietism and stasis. This is necessary because all culture religious or secular - is capable of development and change. Whether we really can provide an equality of public space for the religious and those who would denounce it to re-enter the public sphere is a difficult question for us to answer. Ironically, societies faced by these dilemmas will have to decide how far they can tolerate a conflict model between the religious and the free speech advocate in the name of so-called consensus.

\section{Endnotes}

1 A classic example of this paradigm in use is Keith Thomas's 1971 Religion and the Decline of Magic, London: Weidenfeld and Nicholson.

2 Peter Berger, 1967, The Sacred Canopy: The Social Reality of Religion, Garden City, N.Y.: Doubleday.

${ }^{3}$ We might contrast the Berger version of secularisation with that offered by Bryan Wilson, in his later Religion in Sociological Perspective (Oxford: Oxford University Press 1982). This envisaged religion ceasing to be important in the working of the social system but instead becoming personalised or privatised. Again we may wish to note how Western and Christocentric this analysis is, even for its time. Bryan Wilson also suggested that the process could be measured through churches becoming, among other things, mosques! 
4 Eberhard Sauer, 2003, The Archaeology of Religious Hatred in the Roman and Early Medieval World, Stroud: Tempus Books, pp. 15-18.

5 See Gerda Reith, 1999, The Age of Chance: Gambling in Western Culture, London: Routledge.

6 See Sauer, op. cit.

7 Sauer, ibid., pp. 162-164, 30, 159, 46 and 162.

8 Secularisation theory and its own history can be approached through D.S. Nash, 2004, 'Secularization's failure as a master narrative; Reconnecting Religion with Social and Cultural History', Cultural and Social History, vol. 1, no. 2, pp. 302-325.

${ }^{9}$ See Gerd Schwerhoff, 1998, ‘Starke Worte: Blasphemie als theatralische Inszenierung von Männlichkeit an der Wende vom Mittelalter zur Frühen Neuzeit' in Martin Dinges (ed.), Hausväter, Priest, Kastraten: Zur Konstruktion von Männlichkeit in Spätmittelalter und Früher Neuzeit, Göttingen, pp. 238-263; Alain Cabantous, 2002, Blasphemy: Impious speech in the West from the seventeenth to the nineteenth century, Eric Rauth (trans.), New York: Columbia University Press; and Francisca Loetz, 2002, Mit Gott handeln: von den Zürcher Gotteslästerern der Frühen Neuzeit zu einer Kulturgeschichte des Religiösen, Vandenhoeck and Ruprecht Göttingen.

10 For examples of this, see Maureen Flynn, 1995, 'Blasphemy and the Play of Anger in sixteenth century Spain', Past and Present, vol. 149, pp. 29-56, p.35-36.; Maureen Flynn, 1998, 'Taming Anger's daughters: New treatment for emotional problems in Renaissance Spain,' Renaissance Quarterly, vol. 51, no. 3, pp. 864-886, and Javier Villa-Flores, 2007, 'On Divine Persecution: Blasphemy and Gambling in New Spain' in Susan Schroeder and Stafford Poole (eds.), Religion and Society in Colonial Mexico, New Mexico University Press: New Mexico.

11 It is worth comparing Delumeu's thesis about late medieval Christendom's own obsession with guilt alongside Max Weber's version for post-Reformation Protestant Europe. See Jean Delumeau, 1990 edition, Sin and Fear: The Emergence of a Western Guilt Culture, 13th-18th Centuries, Eric Nicholson (trans.), New York: St. Martin's Press.

12 Marjorie Heins, 1993, Sex, Sin, and Blasphemy: A guide to America's censorship wars, New York: The New Press.

13 Secularisation theory and its own history can be approached through D. S. Nash, 2004,

'Secularization's failure as a master narrative; Reconnecting Religion with Social and Cultural History', Cultural and Social History, vol. 1, no. 2, pp. 302-325.

Interights and Article Nineteen 1995, Blasphemy and Film Censorship, submission to the European Court of Human Rights in respect of Nigel Wingrove v. the United Kingdom. Article 19/Interights, London.

15 See L. Levy, 1993, Blasphemy, Verbal offense against the sacred, from Moses to Salman Rushdie, New York: Knopf, pp. 513-515. See also Theodore Schroeder, 1970, [1919], Constitutional Free Speech Defined and Defended in an Unfinished argument in a case of Blasphemy, New York: De Capo Press, re-print of 1919 edition published by the Free Speech League.

16 Such prosecutions became impossible after Burstyn $v$ Wilson, 343, U.S. 495 (1952).

17 See Heins, op. cit.

18 See the Indian Criminal Code 'imposed' in 1860 which equalised the legal situation between all religious groups in India by outlawing all attacks upon religious artefacts and buildings. Indian Penal Code (1860), sections 295, 295a and 298.

19 A recent contribution in this area is S. Brent Plate, 2006, Blasphemy: Art that Offends, London: Black Dog Publishing.

20 It is worth noting also that individual films are probably just as likely to be viewed in the wider canon of their director than as a manifestation of a particular genre. For an example pertinent to this area, see Lawrence S. Friedman, 1997, The Cinema of Martin Scorsese, Oxford: Roundhouse, and Ian Christie and David Thompson, 2003, Scorsese on Scorsese, London: Faber. 